\title{
Histopathological Effects of Chronic Exposure to Cadmium and Zinc on Kidneys and Gills of Brown Trout (Salmo trutta m. fario)
}

\author{
Hajrudin Beširovicic $^{1, *}$, Amer Alić ${ }^{1}$, Senad Prašović ${ }^{1}$, Wolfgang Drommer ${ }^{2}$ \\ ${ }^{1}$ Faculty of Veterinay Medicine in Sarajevo, Department of VeterinaryPathology, Zmaja od Bosne, 90, 71000 Sarajevo, \\ Bosnia and Herzegovina. \\ ${ }^{2}$ Tierärztliche Hochschule Hannover, Institut für Pathologie, Bünteweg 17, Germany.
}

* Corresponding Author: Tel.: +387.33 6109 08; Fax: ;

Received 15 November 2008

E-mail: bhajrudin@vfs.unsa.ba

\begin{abstract}
The aim of the present study was to investigate the histopathological changes on the organs of the brown trout (Salmo trutta m. fario) inflicted by per oral cadmium and zinc poisoning in the 46- week experimental period. The fish were kept in well-oxygenated freshwater basins which were purposely set for the experiment. During the investigation, we set up two experimental basins along with the control one. We put 30 specimens of one-year-old brown trout of the average weight of 15 grams in each basin. According to Venugopal, peroral toxic doses for fish can not be determined precisely. Accurate lethal doses $\left(\mathrm{LD}_{50}\right.$ and $\left.\mathrm{LD}\right)$ can only be established for a number of laboratory animals. However, it is possible to calculate the approximate toxic doses for fish from peroral lethal doses for rats. The calculated values for cadmium chloride are $4,4 \mathrm{mg} / \mathrm{kg}$ and $11 \mathrm{mg} / \mathrm{kg}$ for zinc sulphate, respectively. In the experimental stage we soaked the fish food in solutions made in conformity with the aforementioned values of cadmium chloride and zink sulphate. As a result, the fish consumed the aforementioned toxic doses in the experimental stage, considering that the feeding regimen included the food ration of $2 \%$ body weight/day.
\end{abstract}

Keywords: Heavy metals, fish, peroral poisoning, histopathological.

Kronik Uygulanan Kadmiyum ve Çinkoya Maruz Kalan Kahverengi Alabalığın (Salmo trutta m. fario) Böbrek ve Solungaçlarına Histopatolojik Etkileri

Özet

$\mathrm{Bu}$ çalışmanın amacı, 46 haftalık deney süresinde beher kadmiyum ve çinko zehirlenmesine uğrayan kahverengi alabalığın (Salmo trutta m. fario) organları üzerindeki histopatolojik değişiklikleri belirlemektir. Balıklar, deney için oluşturulan oksijenli tatlı su havzalarında muhafaza edilmiştir. Araştırma süresince kontrol bölgeyle birlikte iki deney havzası oluşturulmuştur. Her havzaya ortalama ağırlığı 15 gram olan, 30 adet ve bir yaşında kahverengi alabalık koyulmuştur. Venugopal'a göre balıklar için peroral toksik dozlar tam olarak tespit edilemez. Kesin ölümcül dozlar $\left(\mathrm{LD}_{50}\right.$ ve $\left.\mathrm{LD}\right)$ yalnızca birkaç laboratuar hayvanı için tespit edilebilir. Fakat fareler için olan peroral ölümcül dozlardan, balıklar için yaklaşık toksik dozlar hesaplamak mümkündür. Hesaplanan değerler sırasıyla kadmiyum klorür için $4,4 \mathrm{mg} / \mathrm{kg}$ ve çinko sülfat için 11 $\mathrm{mg} / \mathrm{kg}$ 'dır. Deneysel aşamada sözü edilen kadmiyum klorür ve çinko sülfat değerlerine uygun olarak hazırlanan çözeltide balık yemi bekletilmiştir. Sonuç olarak beslenme rejiminin \%2 vücut ağırlı̆̆ı/gün yem rasyonu içerdiği dikkate alındığında balıklar deneysel aşamada bahsi geçen toksik dozları tüketmiştir.

Anahtar Kelimeler: Ağır metaller, balık, oral zehirlenme dozu, histopatolojik etki.

\section{Introduction}

Cadmium is considered as one of the most toxic heavy metals. It is a nonessential element to all living organisms. Rivers and lake shores are the areas primarily affected by diluted cadmium waste from industrial facilities in big cities (Randi, 1996).

The cadmium-related contamination of the aquatic habitat has greatly increased in the last decades, resulting in an increase of cadmium deposits in tissues of aquatic organisms in all food chain systems (Giles, 1988).

It is important to note that cadmium is a highly toxic element for all mammals and fish. Cadmium levels have constantly been increasing, and consequently, the research on cadmium has become quite topical and urgent. Accumulation of cadmium in living organisms is a major ecological concern, 
especially because of its ability to accumulate very quickly. By contrast, the excretion of cadmium from living organisms is a slow process. In fish, cadmium can cause a number of structural and pathomorphological changes in various organs. The highest cadmium levels were detected in the kidneys and liver of fish (Thophon et al., 2003).

Cadmium is noted for its tendency to accumulate in the organisms of mammals for a prolonged biological semi- life. It is responsible for increased hypertension, emphysema, kidney tubule damage, impaired liver function, and cancer (Ribelin and Migaki, 1975).

The study performed on seabass (Dicentrarchus labrax), in the case of acute cadmium poisoning, has shown that the primary site of toxicity are the gills' lamellae and kidney tubules. In the case of subchronic poisoning, the primarily affected organs appear to be kidneys and liver, and to a lesser extent the gills (Thophon et al., 2003).

Heavy metal contamination, above all, by zinc, has become increasingly alarming, especially with regard to depletion of natural resources. This process is a result of a population surge, increased urbanisation, and expansion of industry and ever growing exploitation of natural resources along with the absence of ecological laws. In this situation, the gills' lesions are a potential indicator of water contamination. Skin is another, albeit less important, organ instrumental in evaluating the impact of toxic materials from the surrounding environment on water organisms (Hemalatha and Banerjee, 1997).

The increase of zinc resorption in tubules can cause in a very short time lasting changes related to osmotic nephrosis, possibly through the stabilization of lisosomal membrane which has been affected by zinc. The osmotically changed, convoluted proximal tubules become hypertrophic and hyperplastic. The dose sufficient to cause osmotic-type nephroses also increases frequency and a degree of lesions related to chronic progressive nephropathies (Haschek et al., 2002).

Zinc accumulates evenly in all parts of the kidneys, but the highest concentration appears to be in distal tubules at the site of its filtration (Woodling et al., 2001).

The zinc cytotoxicity is related to the inhibition of the DNA and RNA synthesis which, in turn, jeopardises the protein metabolism in the cell and $\mathrm{Ca}^{++}$antagonism (Walther et al., 2003).

\section{Material and Methods}

\section{Experimental fish}

Thirty specimens of one-year-old brown trout (Salmo trutta m. fario) of the average weight of $15 \mathrm{~g}$, were put in a freshwater basin (hard water) with a water temperature of $9^{\circ} \mathrm{C}$. The fish were kept in basins during the 46-week period and fed with food pellets (at the beginning of the experiment with $2 \mathrm{~mm}$ Biomare granules later to be changed to $3 \mathrm{~mm}$ granules). The fish were fed in compliance with the requirements of a food ration of $2 \%$ body weight/ day. The fish that had survived after 46 weeks were sacrificed and used in further investigation.

\section{Cadmium and Zinc Analyses}

Following the organ extraction (primarily the kidneys) we used the standard atomic absorption spectrophotometry (AAS) method (Perkin Elmer 3003 spectrometer), to detect the content of heavy metals (Cd and $\mathrm{Zn}$ ).

\section{Light Microscopic Study}

\section{Toluidine Blue Staining}

For the staining of semi-thin sections embedded in wax we used the $0.25 \%$ toluidine blue solution. The sections stained with toluidine blue solution were kept on a warm plate at the temperature of 70 to $80^{\circ} \mathrm{C}$. The duration of the staining procedure, dependent on the material, ranged between $1 / 2$ to 2 minutes. Afterwards the sections were washed in distilled water, and dried on the microscopic slides which were placed on a dry plate at the temperature of 70 to $80^{\circ} \mathrm{C}$.

\section{Transmission Electron Microscopic Study}

The fish that had survived the experiment were quickly anesthetized by triciane methane sulfonate for 2-3 min. The kidneys and gills were rapidly removed and routinely processed for transmission electron microscopic study.

The kidneys and gills were cut into $1 \mathrm{~mm}$ pieces and fixed in 4\% glutaraldehide solution for 24 hours. One hour after initial fixation, rinsing in Cacodylated puffer with a $\mathrm{pH}$ value of 7.2 was performed. After that the fixation was carried out again in $1 \%$ osmiumtetraoxide solution for 2 hours. Postfixed tissues were rinsed in filtered water and dehydrated through a graded series of ethanol. Then they were infiltrated with propylene oxide and embedded in Epon 812 . Ultrathin sections $(0,5-1 \mu \mathrm{m})$ were cut by using a glass knive on an "Ultracut E Reichart - Jung" with the thickness of $70 \mathrm{~nm}$, collected on naked copper-meshed grids, and stained with uranyl acetate and lead citrate. The sections were examined and viewed using Zeiss $10 \mathrm{C}$ electron microscope operating at $50 \mathrm{kV}$.

\section{Scanning Electron Microscopic study}

Fragments of gills were fixed in $4 \%$ glutaraldehyde solution for 24 hours. One hour after fixation, multiple rinsing in Cacodylated puffer $(\mathrm{pH}$ 7.2) was performed. After being fixed in $1 \%$ osmiumtetraoxide solution for 2 hours, the sections 
were dehydrated in a graded series of ethanol. Then the tissue pieces were dried by the Critical Point method (model E 3000). Prior to final drying of sections by the Critical Point method, it is necessary to keep them in acetic acid - amylacetate solution for two days. The coated specimens were examined by the scanning electron microscope Zeiss under $15 \mathrm{kV}$.

\section{Results}

\section{Chronic Exposure}

Fish in the control basin swam normally without any signs of abnormality. Fish in the experimental basins did not show any abnormality either except in the $23^{\text {rd }}$ week when their swimming movements decreased, along with a reduced feeding activity. Fish that died before the end of the experiment were also investigated.

At the end of the experiment the average cadmium concentration in proximal kidney tubules was analyzed by the atomic absorption spectrophotometer, and it amounted to $51 \mu \mathrm{g} / \mathrm{g}$ wet weight, while the average cadmium concentration in the gills was $2.03 \mu \mathrm{g} / \mathrm{g}$ wet wt.

\section{Histopathological Observation}

In one out of 30 fish, the backbone deformity in the form of scoliosis was detected by rentgenological examination (Figure 1).

\section{Gills}

Raster-electron microscopy showed clear intumescences of secondary lamellae of the gills after cadmium poisoning (Figure 2, 3, 4).

In some cases, proteinaceous filamentous content was observed which caused the gluing of secondary lamellae, indicating the possibility of their significantly reduced function (Figure 4).

\section{Kidney}

The cadmium poisoning caused greater degenerative changes in the epithelial cells of the kidney tubules, their vacuolization, and accumulation of the proteinaceous content in the Bowman's capsule space. In the transmission electron microphotographs, these vacuoles displayed the fine granular proteinaceous content (Figures 5-9).

The vacuoles observed in the cytoplasm of the kidney tubules' epithelial cells may be an indicator of hydropic degeneration. The mitochondrial proliferation is also noticeable (Figure 10).

Furthermore, the accumulation of osmophilic material was observed in the cytoplasm of epithelial cells of the kidney tubules. This material cannot be determined with absolute certainty under the electron microscope. Osmophilic bodies may contain fat droplets, along with heavy metals that absorb electrons. However, there is no conclusive evidence to make a value judgment in this respect (Figures 11 and 12).

\section{Zinc-poisoned fish}

Similarly to fish poisoned by cadmium, those poisoned by zinc did not show any signs of abnormality either. In the latter group, the histopathological changes in the form of ulcers were spotted on the skin of some fish. These changes are estimated to be caused by the basin habitat and could not be connected with the changes related to longterm zinc ingestion.

\section{Kidney}

After examining the semi-thin sections of the kidneys from zinc-poisoned fish under the light microscope we can conclude that zinc causes hyperplasia of the epithelial cells in the kidney tubules, but also the appearance of small dark granules in their cytoplasm (Figures 13 and 14).

The transmission electron microscopic examination also showed that after zinc poisoning the kidney tubules' epithelial cells contained monomorphous osmophilic granules and particles with a light crystal structure (Figure 15).

Figure 16 shows that the kidney tubules' epithelial cells contain diffusely scattered small vacuoles, while the tubular lumen contains proteinrich granules. The translucent membranes of damaged cells can also be observed in the tubular lumen. This, in turn, indicates that reabsorbed substances, along with damaged membranes will be expelled into the tubular lumen through the tubular system (Figure 17). The macrophages phagocytosing degenerated cells are also visible in the tubular lumen (Figure 18).

\section{Discussion}

In his investigations Olsson (1998) reported inter alia that cadmium can primarily cause the backbone deformities in fish. However, diagnostically, the deformity could also be caused by musculature spasms. Furthermore, Halsband et al. (1984) also reported on backbone deformities manifested in the form of scoliosis, and compression (shortening of the vertebral column). Taking into consideration the fact that the latter change was found only in one fish out of 30 fish specimens in our experiment, we cannot claim with certainty that the aforementioned change was caused by cadmium ingestion.

According to Ribelin and Migiaki (1975), and Tanimoto et al. (1999) cadmium is responsible for the pathological changes of kidney tubules, and these findings were also confirmed by the results of our investigation related to the kidneys of fish that were 


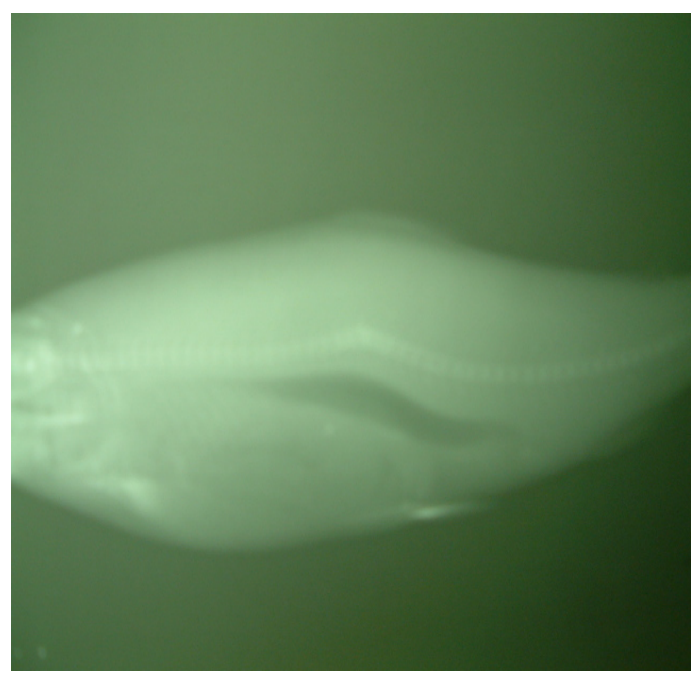

Figure 1. Backbone scoliosis (Lateral view)

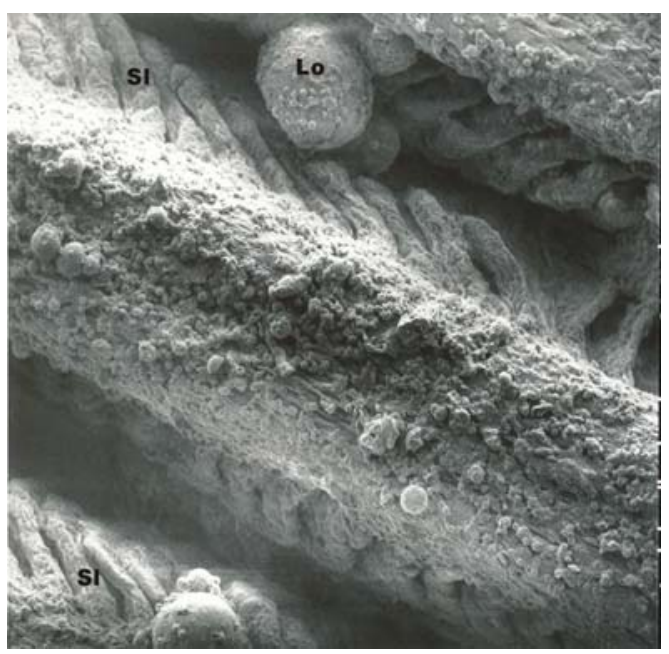

Figure 3. Rastelelectron microphoto of secondary lamellae with clear swelling and enlargement (Lo). $2680 \mathrm{X}$

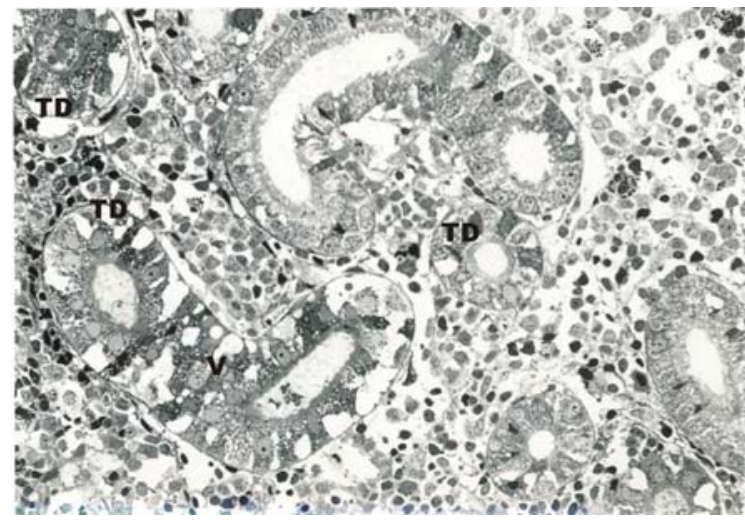

Figure 5. Semithin section. The transverse section of the tubule. Tubular cells show degeneration (TD), and a large number of vacuoles $(\mathrm{V})$ in the cytoplasm of epithelial cells. (Toluidine blue staining) 400

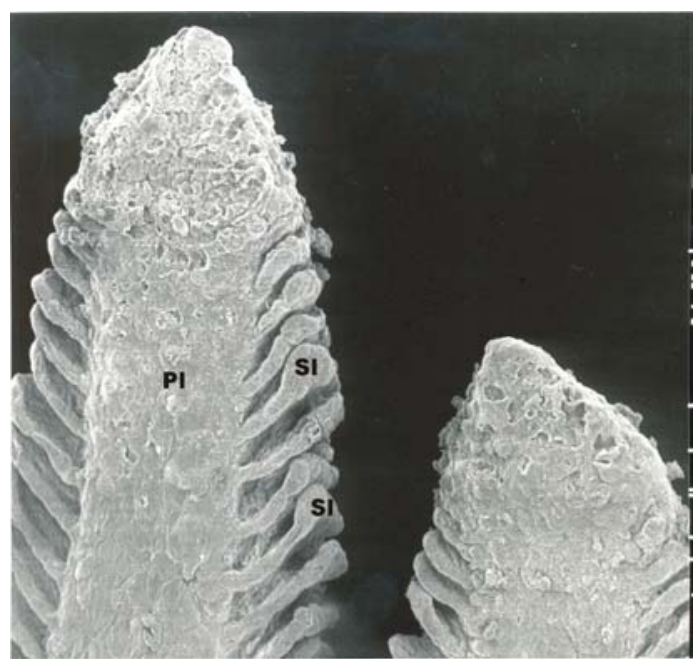

Figure 2. The primary lamella $(\mathrm{Pl})$ with intumescence of the secondary lamellae (S1). $2800 \mathrm{X}$

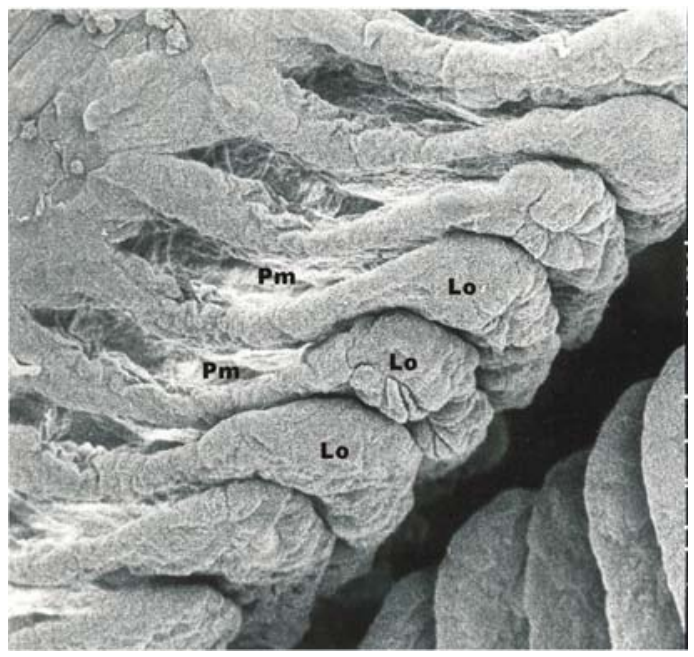

Figure 4. REM micro photo. Intumescent secondary lamellae at the margins (Lo) and clear gluing with proteinaceous filamentous content $(\mathrm{Pm})$, possibly the fibrin. $2680 \mathrm{X}$.

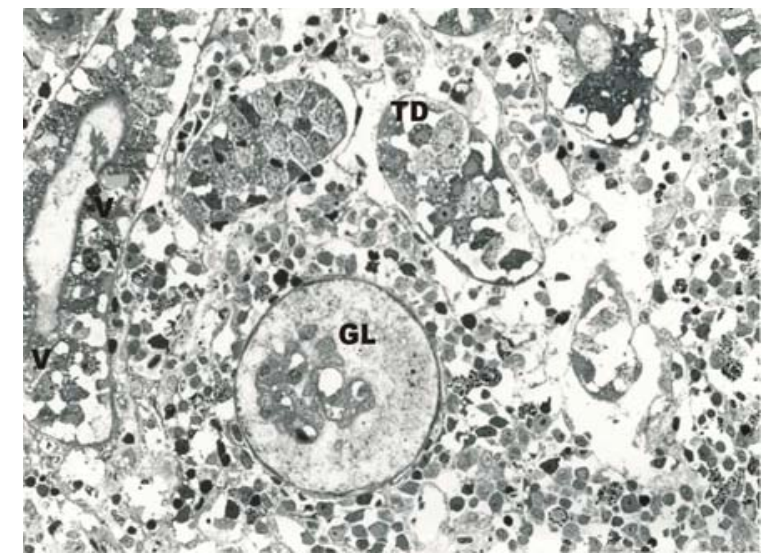

Figure 6. The glomerul (GL) with proteinaceous content in the space of Bowman's capsule. Epithelial cells of kidney tubules with degenerative changes (TD) and vacuoles (V) that are clearly visible on transmision-electronmicrographs. (Toluidine blue staining) $400 \mathrm{x}$ 


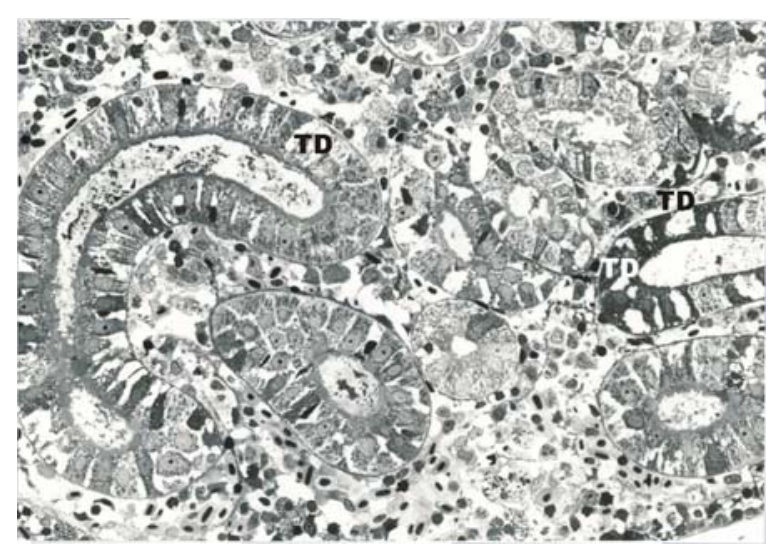

Figure 7. The transverse section of the kidney tubule with a clearly visible degeneration of the tubular epithelial cells (TD). (Toluidine blue staining).

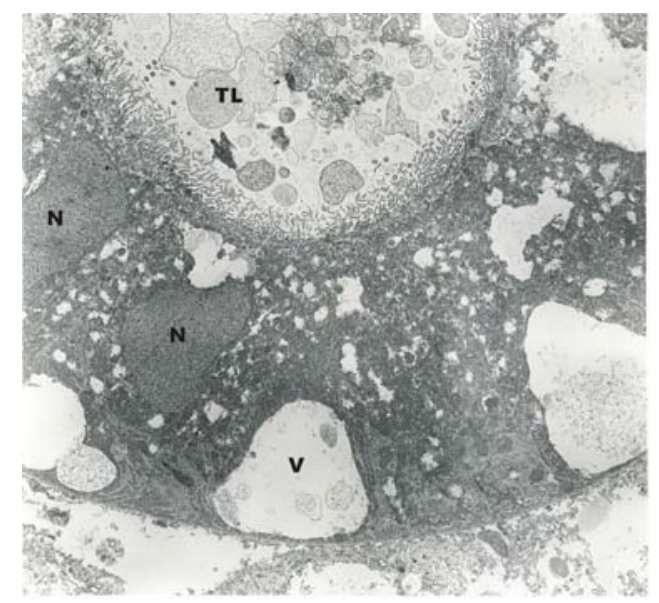

Figure 9. The transverse section of the tubule with nucleolus (N) and large vacuoles in the cytoplasm (V). In the vacuoles there was a fine granular proteinaceous content. In the tubular lumen, the vesicles of the different size can be observed, probably representing the eventration of tubular epithelium into the lumen. (TL). X 4000

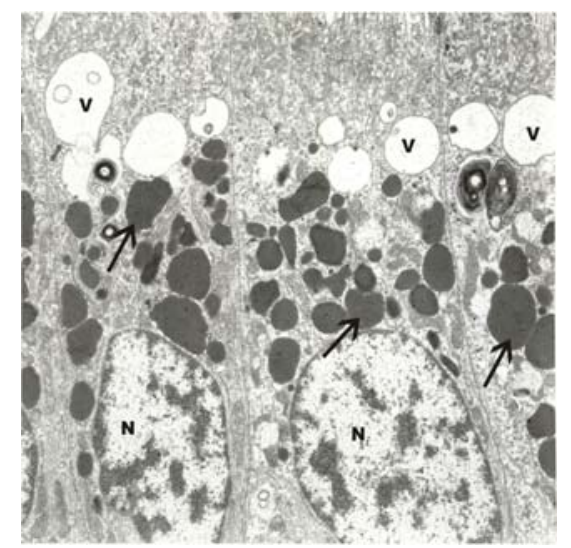

Figure 11. Nuclei of epithelial cells. The gathering of a large number of vacuoles (V) and abundancy of osmophilic bodies of different sizez (arrows). X 8000

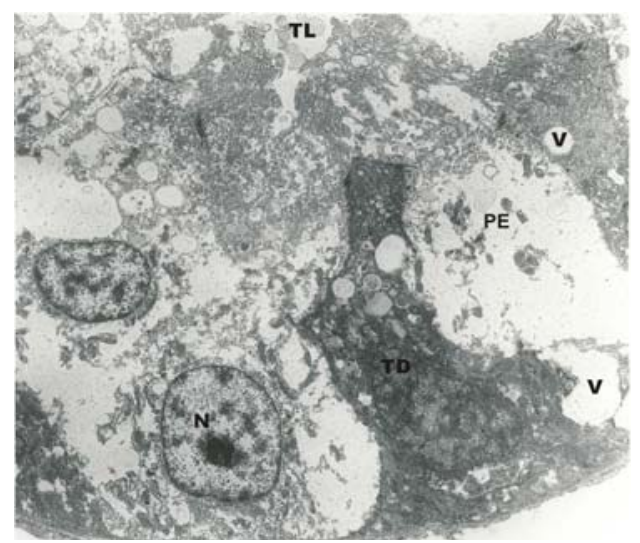

Figure 8. Miocrophotograph (TEM) of the transverse section of the tubule with degenerative changes of the epithelial cells (TD), large vacuoles (V), and damaged epithelial cells (PE). X 5040

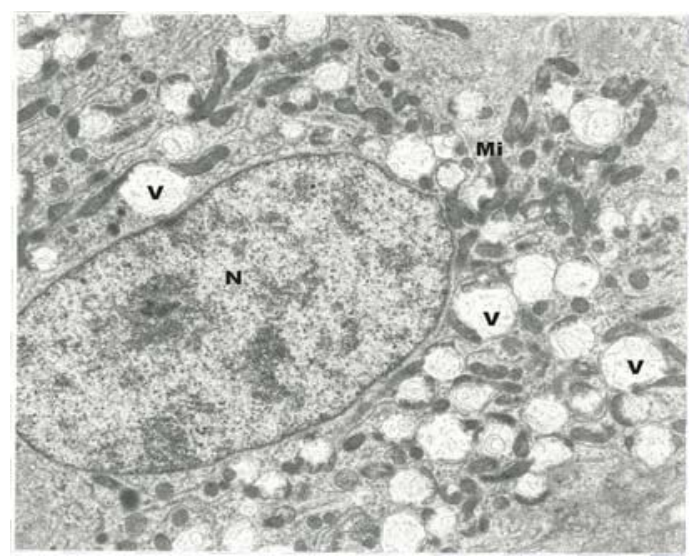

Figure 10. A detail of the magnified single epithelial cell with the nucleus $(\mathrm{N})$ and a large number of vacuoles $(\mathrm{V})$. Vacuoles probably represent the hydropic degeneration. Besides vacuoles the mitochondrial proliferation (Mi) with pathological changes is also noticeable. X 10000

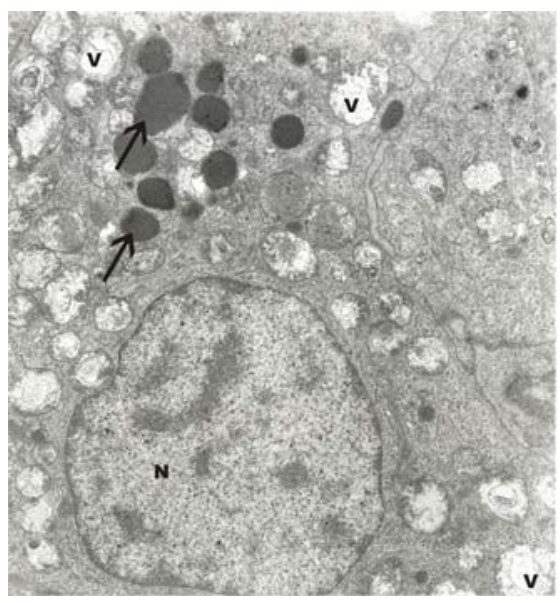

Figure 12. Tubular epithelial cells with nucleus (N), a great number of vacuoles $(\mathrm{V})$, and osmophilic bodies (arrows) of different sizes. The content of vacuoles is mostly homogenous. X 10000 


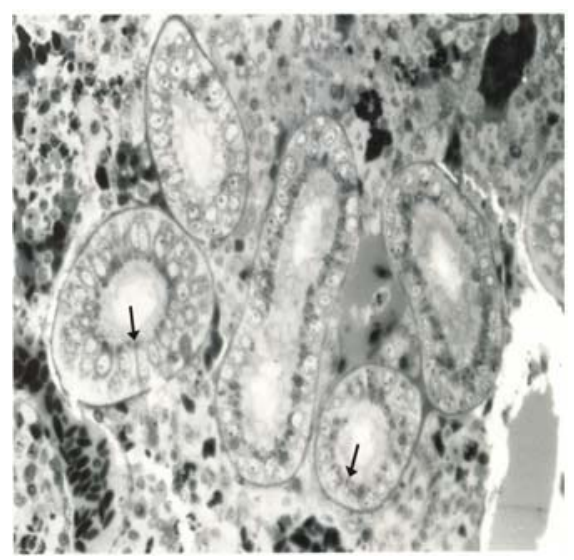

Figure 13. The semithin trans- section of the tubule. Epithelial cells contain small dark granules in the cytoplasm (arrow). X 400

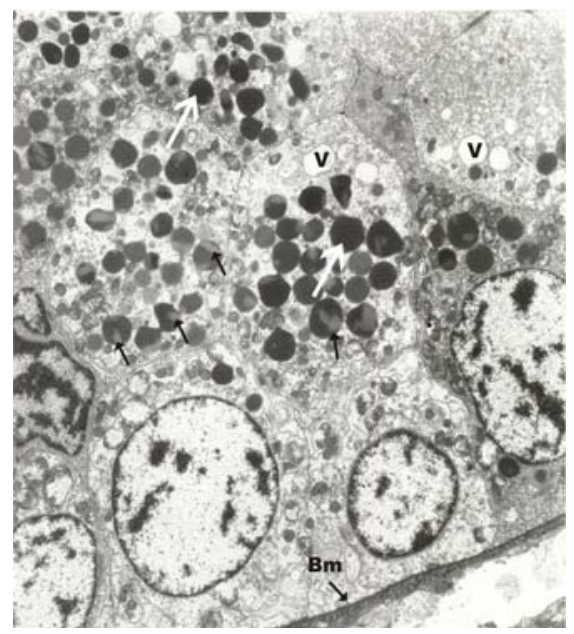

Figure 15. TEM photomicrograph of the tubular epithelial cells with many osmophilic granules (white arrows). These granules contain a characteritic white crystal structure (arrows) that differ in size. This structure is observed only in fish poisoned with zinc. There $i$ as lesser number of vacuoles $(\mathrm{V})$ in the epithelial cells. The basal membrane is well tinged, and varies in thicknes. X 5000.

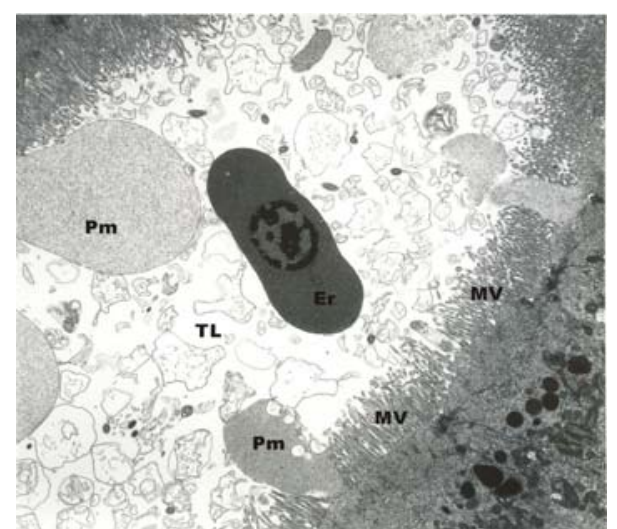

Figure 17. TEM photomicrograph of the tubular lumen (TL), tangent section, with erythrocyte (Er) and a great number of the protein- rich vacuoles $(\mathrm{Pm})$. One vacuole shows exocytosis of material (v.s) from the cytoplasm. Some membranes are visible in the tubule. Microvilli (MV) show a normal structure. X 5000.

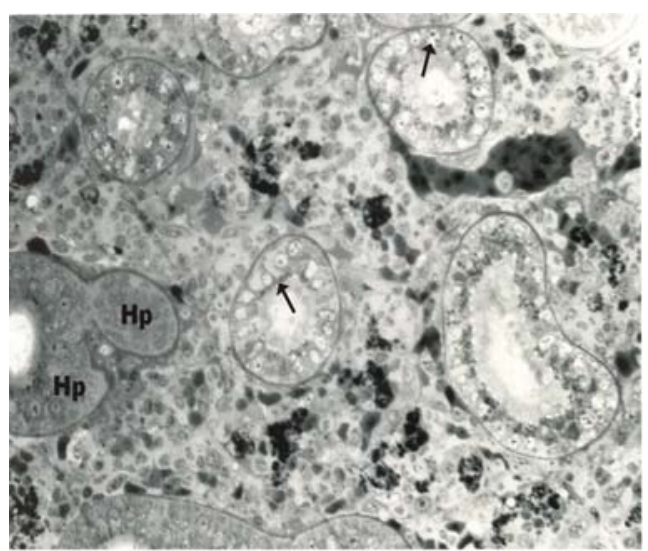

Figure 14. Semithin sections of the kidney tubules. One tubule displays hyperplasia (Hp). There is a great number of dark granules in the apical sections of the tubular epithelial cells. X 400.

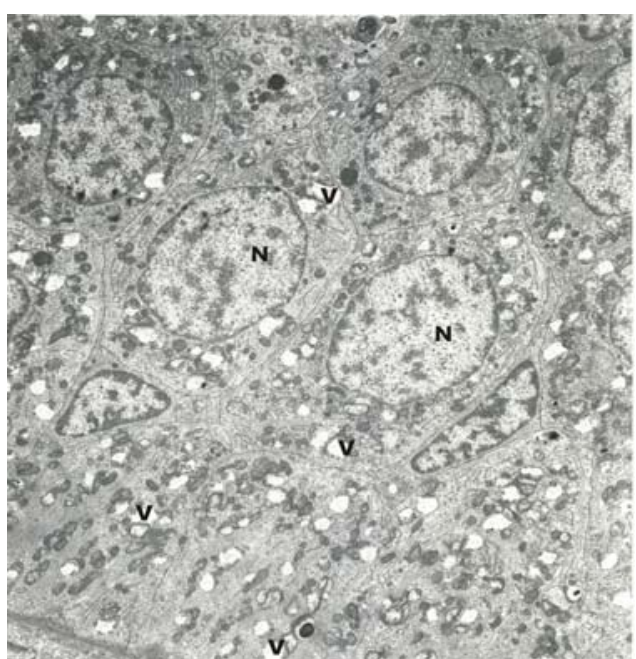

Figure 16. TEM photomicrograph of cells with normal nucleus $(\mathrm{N})$ and diffusely localized vacuoles (V). X 5000

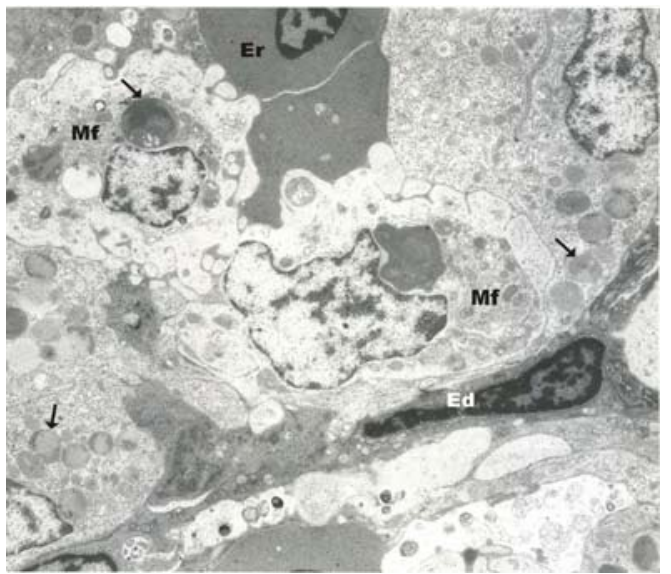

Figure 18. TEM photomicrograph of the tangent section of the blood vessel with visible endothelium (Ed). The erythrocytes and macrophages phagocytosing degenerated cells are visible in the lumen. Furthermore, some macrophages contain particles (arrow) whose thicknes varies. X 5000. 
purposely poisoned during the experimental stage. (see Figures 4, 5, 6 and 7). Bubel (1976) reported that cadmium had particularly adverse effects on the mitochondrial membrane, by means of crystal accumulation that greatly reduced the synthesis of ATP. In our electron micrographic investigation (Figure 9) the mitochondrial proliferation was noticed, but crystal sediments on mitochondria were not observed. No definitive conclusion can be made in regard of the absence of crystal sedimentation. A possible explanation may be that a longer period is required for these sediments to be formed. At this, it should be noted that our experiment was carried out in a 46-week period. The changes found on gills (Figures 1, 2 and 3) were gluing and hyperplasia of secondary lamellae. Our research results in this respect are supported by the findings of Thophon et al. (2004). The aforementioned changes could cause a lethal outcome due to gas exchange failure. We can say with certainty that this pathological change was caused by cadmium poisoning, and it is in conformity with the research findings of Randi et al. (1996) who also reported on this, by and large, non-specific pathological change, provided that the exposure period to cadmium poisoning was longer than 60 days. As indicated earlier, our experiment was conducted during a much longer period. Shore and Douben (1994) remarked that the kidney is a critical organ affected by cadmium poisoning since the pathological changes are primarily observed on this organ. Our research findings confirm that the major pathological changes occurred in proximal tubules whose epithelium showed atrophy and vacuolar degeneration (see Figures 4, 5, 6 and 7), and different forms of nephritis, but rarely a single cell necrosis. A typical change, observed under the electron microscope, was the occurrence of fatty droplets and dark granules in the cytoplasm of tubular epithelial cells (Figures 10 and 11). The accumulation of these fatty droplets and dark granules caused the tear of cytoplasmic organelles, and sporadic tubular necrosis along with a degeneration of tubular cells, which was also found in our investigation.

The available literature data related to zinc poisoning of fish proves that zinc is reabsorbed in great amounts in the proximal tubules, and as a result, the tubules become hypertrophic and hyperplastic (Figure 14). The aforementioned findings were also reported by Haschek et al. (2002). In conformity with the results obtained by electron microscopic examination we may conclude that the osmophilic granules and particles found in the cytoplasm of the kidney's epithelial cells can be linked to zinc poisoning (Figures 13 and 15). In their study Walther et al. (2003) assert that zinc endangers protein metabolism in the cell and this feature (property) of zinc could account for the occurance of granules observed in the tubules (Figure 15) as well as for the damaged cells in the tubular system of the kidneys (Figure 17). We could not find any relevant data in the literature pertaining to our research findings of the monomorphous osmophilic granules (Figures 13, 14 and 15) and particles with a bright crystal structure (Figure 15). So far, we have not been able to determine the scientific nature of the said phenomena.

\section{Conclusions}

Our research findings show that cadmium poisoning of fish caused a severe degeneration of kidney epithelial cells, along with the enlargement of secondary lamellae on the gills and their gluing. These findings are in conformity with those obtained in other relevant studies on this particular issue.

According to electron microscopy investigation results it can be reported that the epithelial cells of the kidney tubules following zinc poisoning contain the monomorphous osmophilic granules and particles with a bright crystal structure in the central region.

\section{Aknowledgments}

We gratefully acknowledge the assistance of the "Bosnia Hoteli" chain in granting us permission to use part of their fish farm facilities for our experiments.

\section{References}

Bubel, A. 1976. Histological and Electron Microscopical Observations on the Effects of Different Salinities and Heavy Metal Ions, on the Gills of Jaera nordmanni (Rathke) (Crustacea, Isopoda). Cell Tiss. Res., 167: 6595.

Giles, M. A. 1988. Accumulation of Cadmium by Rainbow Trout, Salmo gairdneri, during Extended Exposure. Can. J. Fish. Aqut. Sci., 45: 1045-1053.

Haschek, M.W., Rousseaux, G.C. and Wallig, A.M. 2002. Handbook of Toxicologic Pathology, Second Edition, Academic Press. San Diego, 1706 pp.

Halsband, E., Halsband, I. and Pump, H. 1984. Die wirkung von Cadmium auf Das Blutbild, die Organe und das Skelettsystem von Forellen sowie die beeinflussung durch kristallisiertes Dihydrotachysterol und Calcium. Fisch und Umwelt, Hefte Gustav Fischer Verlag, 13: 139-177.

Hemalatha, S. and Banerjee, T.K. 1997. Estimation of sublethal toxicity of zinc chloride by histopathological analysis if fish (Heteropneustes fossilis, Bloch) epidermis. Current science, 73(7): 614-621.

Olsson, P.E. 1998. Disorders Associated with Heavy Metal Pollution. In: J.F. Leatherland and P.T.K. Woo (eds), Fish Diseases and Disorders, Non-infectious Disordes. CABI Publishing, Wallingford: 105-131.

Randi, A.S., Monserrat, J.M., Rodriquez, E.M. and Romano, L.A. 1996. Histopathological effects of cadmium on the gills of the freshwater fish, Macropsobrycon uruguayanae Eigenmann 1915 (Pisces, Atherinidae). J. of Fish Diseases, 19: 311-322.

Ribelin, W.E. and Migaki, G. 1975. The Pathology of Fishes. The University of Wisconsin Press, Madison, Wisconsin, 537 pp.

Shore, F.R. and Douben, E.T.P. 1994. The Ecotoxicological 
Significance of Cadmium Intake and residues in Terrestrial Small Mammals. Ecotoxicology and Environmental Safety, 29: 101-112.

Tanimoto, A., Hamada, T., Higashi, K., and Sasaguri, Y. 1999. Distribution of cadmium and metallothionein in $\mathrm{CdCl}_{2}$-exposed rat kidney: Relationship with apoptosis and regeneration. Pathology International, 49: $125-132$

Thophon, S., Kruatrachue, M., Upatham, E.S., Pokethitiyook, P., Sahaphong, S. and Jaritkhuan, S. 2003. Histopathological alterations of white seabass, Lates calcalifer, in acute and subchronic cadmium exposure. Environmental Pollution, 121: 307-320.

Thophon, S., Pokethitiyook, P., Chalermawt, K., Upatham, Suchart, E. and Sahaphong, S. 2004. Ultrastructural
Alterations in the Liver and Kidney of White Sea Bass, Lates calcalifer, in Acute and Subchronic Cadmium Exposure. Environmental Toxicology, 19: 11-19.

Venugopal, B. and Luckey, T.D. 1978. Metal toxicity in mammals I. Plenum Press, New York, 101 pp.

Woodling, J.D., Brinkman, S.F. and Horn, B.J. 2001. Nonuniform Accumulation of Cadmium and Copper in Kidneys of Wild Brown trout (Salmo trutta) populations. Archives of Environmental Contamination and Toxicology, 40: 381-385.

Walther, U.I., Czermak, A., Mückter, S.C. and Fichtl, B. 2003. Decreased GSSG reductase activity enhances cellular zinc toxicity in the three human lung cell lines. Archives of Toxicology, 77: 131-137. 